\title{
Pengaruh Lama Pengasinan Pada Pembuatan Telur Asin dengan Cara Basah
}

\section{The Effect of Marinating Time in Salted Egg Production Using Wet Method}

\author{
A Engelen'1a, S Umela1, A A Hasan'1 \\ ${ }^{1}$ Politeknik Gorontalo, Jl. Muchlis Rahim, Desa Panggulo Barat, KecamatanBotupingge, Provinsi \\ Gorontalo, Kode Pos96583, \\ aKorespondensi: Adnan Engelen, Email: adnanengelen@poligon.ac.id
}

(Diterima oleh Dewan Redaksi: 30-08-2017)

(Dipublikasikan oleh Dewan Redaksi: 25-10-2017)

\begin{abstract}
The purpose of the research is to determine how marinating time effect the egg nutrition in the salted egg production using wet method. Salted egg consumption is considered to be quite high. However, there is no information about the recommended marinating time to be able to produce high quality salted egg. This research is using different sets of marinated time such as $3,6,9,12,15,18$, and 21 days to produce salted egg using wet method. The nutritional parameter to be analysis are fat content, $\mathrm{pH}, \mathrm{NaCl}$, and water content. Analysis result of marinating time effect to the salted egg nutritionusing ANOVA Analysis Of Variance showed that the fat content of the yolk $(128,94 \%)$, fat egg white $(0,18 \%), \mathrm{pH}$ of the egg yolk $(0,16 \%), \mathrm{pH}$ of the egg white $(0,34 \%), \mathrm{NaCl}$ of the egg yolk $(0,71 \%), \mathrm{NaCl}$ of the egg white $(0,77 \%)$, the water content of the egg yolk $(63,93 \%)$, the water content of the egg white $(0,81 \%)$. These results showed that marinating time in the process of salted egg productionhas no real effect.
\end{abstract}

Keywords: Duck egg, salt, marinating

\begin{abstract}
ABSTRAK
Penelitian ini bertujuan untuk mengetahui lama pengasinan terhadap kandungan zat gizi telur itik pada pembuatan telur asin dengan cara basah. Konsumsi telur asin dimasyarakat cukup tinggi. Namun, pada proses pembuatan telur asin belum diketahui secara pasti lama pengasinan terbaik sehingga dibutuhkan penelitian agar mengetahui lama pengasinan terbaik pada pembuatan telur asin. Penelitian ini merupakan penelitian dengan lama pengasinan $3,6,9,12,15,18$, dan 21 hari pada pembuatan telur bebek mentah cara basah. Adapun parameter gizi yang akan diuji adalah analisis kadar lemak, $\mathrm{pH}, \mathrm{NaCl}$, dan kadar air. Hasil Analisis Ragam Anova didapatkan bahwa pengaruh lama pengasinan 3, 6, 9, 12, 15, 18, dan 21 hari adalah kadar lemak kuning telur $(128,94 \%)$, kadar lemak putih telur $(0,18 \%)$, kadar $\mathrm{pH}$ kuning telur $(0,16 \%)$, kadar $\mathrm{pH}$ putih telur $(0,34 \%)$, kadar $\mathrm{NaCl}$ kuning telur $(0,71 \%)$, kadar $\mathrm{NaCl}$ putih telur $(0,77 \%)$, kadar air kuning telur $(63,93 \%)$, kadar air putih telur $(0,81 \%)$. Hasil tersebut menunjukkan bahwa lama pengasinan terhadap telur asin tidak berpengaruh nyata.
\end{abstract}

Kata kunci: Telur itik, garam, lama pengasinan

A Engelen, S Umela, A A Hasan. 2017. Pengaruh Lama Pengasinan pada Pembuatan Telur Asin dengan Cara Basah.Jurnal Agroindustri Halal3(2): 133 - 141. 


\section{PENDAHULUAN}

Salah satu jenis telur unggas yang paling banyak dikonsumsi masyarakat adalah telur itik (Wibowo, 2011; Noviaet al. 2014). Kandungan gizi telur itik sangat dipengaruhi oleh pakan yang dikonsumsi oleh itik tersebut (Maijon Purba, 2015;Oriestaet al. 2016). Kandungan gizi yang terkandung didalam telur yaitu air, protein, lemak, karbohidrat, asam lemak tidak jenuh serta beberapa vitamin dan mineral. Telur asin merupakan produk telur yang kaya nutrisi dan merupakan hasil olahan yang melibatkan proses pengasinan dan pemanasan(Ganesan et al. 2014). Proses tersebut akan mempengaruhi nilai gizi dan karakteristik fisik dari telur yang dihasilkan (Wibawanti et al. 2013).

Telur itik merupakan salah satu sumber gizi yang baik(Wibowo, 2011), dengan kandungan protein 13,1\%, kalori dan lemak lebih tinggi dari pada telur ayam. Telur itik memiliki bau amis yang tajam, sehingga penggunaan telur itik dalam berbagai makanan tidak seluas telur ayam. Bobot dan ukuran telur itik rata-rata lebih besar dari pada telur ayam, berkisar antara 70-80 g per butir.Cangkang telur itik berwarna biru muda, sehingga telur itik sangat lazim diasinkan karena penetrasi garam ke dalam telur pada telur itik lebih mudah(Octarisaet al. 2013).

Telur itik mempunyai cangkang yang relatif lebih tebal dan rasa telur asin yang lebih enak dan lebih disukai dibandingkan dengan jenis telur yang lain, sehingga secara ekonomis lebih menguntungkan. Salah satu kelemahan telur itik yaitu mudah mengalami kerusakan seperti telur unggas lainnya baik secara fisik, kimia, maupun oleh mikroba. Kerusakan yang terjadi pada telur akan mempengaruhi kualitas dan daya simpan telur. Agar dapat mempertahankan kualitas telur maka dapat dilakukan pengawetan melalui proses pengasinan sehingga kerusakan telur dapat dihambat(Lesmayati dan Rohaeni, 2014). Pengawetan telur bertujuan untuk mempertahankan kualitas dan memperpanjang daya simpan telur. Peningkatan konsumsi telur asin dapat dilakukan dengan pembuatan telur asin dengan cara basah.

Lama pengasinan terhadap metode pengasinan telur cara basah dapat menentukan kualitas dari telur asin yang akan dibuat. Untuk menentukan kualitas tersebut maka perlu diadakan penelitian tentang lama pengasinan terhadap kadar lemak, $\mathrm{pH}, \mathrm{NaCl}$, dan kadar air telur itik. Oleh karena itu, hasil penelitian ini bertujuan untuk mengetahui lama pengasinan terbaik yang akan digunakan pada pengawetan telur.

\section{METODE PENELITIAN}

\section{Alat dan Bahan}

Bahan-bahan yang digunakan dalam penelitian ini terdiri dari telur itik, $\mathrm{NaCl}$, air mineral, baskom, plastik dan bahan-bahan untuk analisis. Alat-alat yang digunakan dalam penelitian ini adalah $\mathrm{pH}$ meter, soxhlet, refraktometer $\mathrm{NaCl}$ AMR 101 , oven, penangas, dan alat-alat pendukung lainnya.

\section{Metode}

Metode penelitian yang digunakan terdiri dari dua tahapan yaitu: 1) penentuan lama pengasinan telur itik dan pembuatan telur asin, 2) prosedur analisis gizi telur itik berupa kadar lemak, $\mathrm{pH}$, $\mathrm{NaCl}$, dan kadar air.

\section{Penentuan Lama Pengasinan Telur Itik}

Penentuan lama pengasinan telur itik dilakukan dengan lama pengasinan 0 , $3,6,9,12,15,18$, dan 21 hari pada telur bebek mentah dalam pembuatan telur asin cara basah. Sampel yang digunakan adalah telur bebek yang dibeli dari pasar Sentral Kota Gorontalo dengan berat telur 
berkisar 65-75 g (Zhao et al. 2016). Parameter yang diteliti adalah kadar lemak, $\mathrm{pH}, \mathrm{NaCl}$, dan kadar air.

\section{Prosedur Analisis giziTelur Itik}

Analisis kadar lemak (SNI, 1992).Sampel ditimbang sebanyak 1-2 glalu ditambah $30 \mathrm{~mL} \mathrm{HCl} 25 \%$ dan $20 \mathrm{~mL}$ air. Sampel didihkan selama 15 menit di ruang asam kemudian disaring dengan kertas saring dalam keadaan panas. Selanjutnya, kertas saring dicuci dengan air panas hingga tidak asam lagi. Kertas saring berikut isinya dikeringkan pada suhu $80^{\circ} \mathrm{C}$. Selanjutnya, kertas saring dilipat dan analisis dilanjutkan pada tahap ekstraksi.

Labu lemak yang akan digunakan untuk mengekstraksi dikeringkan di dalam oven bersuhu $100-110^{\circ} \mathrm{C}$ selama 15 menit, didinginkan dalam desikator selama 5 menit, kemudian ditimbang. Kertas saring hasil hidrolisis sebelumnya dimasukkan ke dalam selongsong kertas saring baru dan disumbat kapas pada sisi atas dan bawahnya, kemudian dimasukkan ke dalam alat ekstraksi yang telah berisi pelarut hexana. Refluks dilakukan selama 6 jam dan pelarut yang ada di dalam labu lemak didistilasi. Selanjutnya, labu lemak yang berisi lemak hasil ekstraksi dipanaskan dalam oven bersuhu $105^{\circ} \mathrm{C}$ hingga beratnya konstan, didinginkan dalam desikator, dan ditimbang. Penghitungan kadar lemak berdasarkan rumus :

$\%$ lemak $=\frac{W-W 1}{W 2} \times 100 \%$

Ket. $\mathrm{W}=$ bobot contoh $(\mathrm{g})$

$\mathrm{W} 1=$ bobot lemak sebelum ekstraksi (g)

$\mathrm{W} 2$ = bobot labu lemak setelah ekstraksi (g)

Analisis Kadar pH (Djaelani, 2016).Pengukuran $\mathrm{pH}$ telur diukur dengan menggunakan $\mathrm{pH}$ meter. Albumen dan yolk dimasukkan ke dalam gelas piala kecil dan diaduk sampai rata, lalu dilakukan pengukuran dengan menggunakan $\mathrm{pH}$ meter. Pengukuran dilakukan 3 kali kemudian hasil diambil rata-rata nilai yang didapatkan.

Analisis Kadar NaCl. Pengukuran kadar $\mathrm{NaCl}$ telur asin dengan menggunakan alat refraktometer AMR 101. Refraktometer adalah instrumen optik yang mempekerjakan pengukuran indeks bias untuk menentukan konsentrasi dalam larutan air. Metode ini sederhana dan cepat. Sampel diukur setelah kalibrasi pengguna yang sederhana dengan air deionisasi atau suling. Dalam hitungan detik instrumen mengukur indeks bias sampel dan mengkonversi ke unit konsentrasi \%.

Analisis Kadar Air (Wibawanti et al. 2013).Telur yang digunakan adalah telur asin mentah sebanyak 3 butir yang dipisahkan bagian putih dan kuningnya untuk masing-masing perlakuan. Telur yang telah dipisahkan bagian putih dan kuning tersebut kemudian dihomogenisasi. Setiap sampel diambil sebanyak 4-5 g lalu dimasukkan ke dalam cawan porselin yang telah diketahui bobotnya. Cawan berisi sampel tersebut dimasukkan ke dalam oven bersuhu $105^{\circ} \mathrm{C}$ selama 15 menit. Setelah itu, cawan didinginkan dalarn desikator selama 15 menit kemudian ditimbang kembali. Kadar air putih dan kuning telur dihitung dengan menggunakan mmus dibawah ini :

Kadar air $(\% \mathrm{bb})=\frac{(x-y)}{(x-a)} \times 100 \%$

Ket. $\quad \mathrm{x}=$ berat cawan dan sampel sebelum dikeringkan (g)] $\mathrm{y}=$ berat cawan dan sampel setelah dikeringkan (g) $\mathrm{a}=$ berat cawan kosong $(\mathrm{g})$ 


\section{HASIL DAN PEMBAHASAN}

\section{Penentuan Lama Pengasinan Telur Itik dan Pembuatan Telur Asin}

Pengaruh Penentuan lama pengasinan telur itik dilakukan dengan lama pengasinan $0,3,6,9,12,15,18$, dan 21 hari. Lama pengasinan menggunakan larutan garam jenuh. Pembuatan larutan garam jenuh dilakukan dengan menambahkan $\mathrm{NaCl}$ ke dalam air yang dipanaskan. Pada konsentrasi tertentu $\mathrm{NaCl}$ tidak larut dalam air, $\mathrm{NaCl}$ yang sudah tidak larut dalam larutan menunjukkan bahwa larutan tersebut sudah jenuh. Larutan garam jenuh yang digunakan sebanyak $6 \mathrm{~L}$ air berbanding $1,5 \mathrm{~kg} \mathrm{NaCl}$. Adapun hasil perbandingan yang didapatkan untuk memperoleh larutan garam jenuh adalah :

Tabel 1. Pembuatan larutan garam jenuh

\begin{tabular}{ccc}
\hline $\mathrm{NaCl}(\mathrm{g})$ & Air $(\mathrm{mL})$ & Hasil \\
\hline 20 & 10 & Larutan tidak jenuh \\
40 & 10 & Larutan jenuh \\
1500 & 6000 & Larutan jenuh \\
\hline
\end{tabular}

Pembuatan telur asin dilakukan dengan membersihkan kotoran-kotoran yang masih melekat pada kulit telur sehingga penetrasi garam ke dalam telur lebih maksimal. Setelah dilakukan pembersihan dengan cara pencucian, telur ditiriskan dan dikering udara. Larutan garam jenuh dibuat sesuai dengan perlakukan pada Tabel 1. Larutan garam jenuh yang masih panas, didinginkan terlebih dahulu kemudian dituangkan ke dalam wadah yang berisi telur. Pembuatan telur asin dilakukan dengan perendaman telur selama $0,3,6,9,12,15,18$, dan 21 hari. Gambar 1 menunjukkan proses pembuatan telur asin.

\section{Analisis Gizi Telur Itik}

Rata-rata kadar lemak, $\mathrm{pH}, \mathrm{NaCl}$, dan kadar air telur asin yang melalui proses perendaman larutan garam jenuh dapat diihat pada Tabel 2. Data pada Tabel 2 menunjukkan pengaruh perendaman telur itik ke larutan garam jenuh pada 0,3 , $6,9,12,15,18$, dan 21 hari tidak memiliki pengaruh nyata.

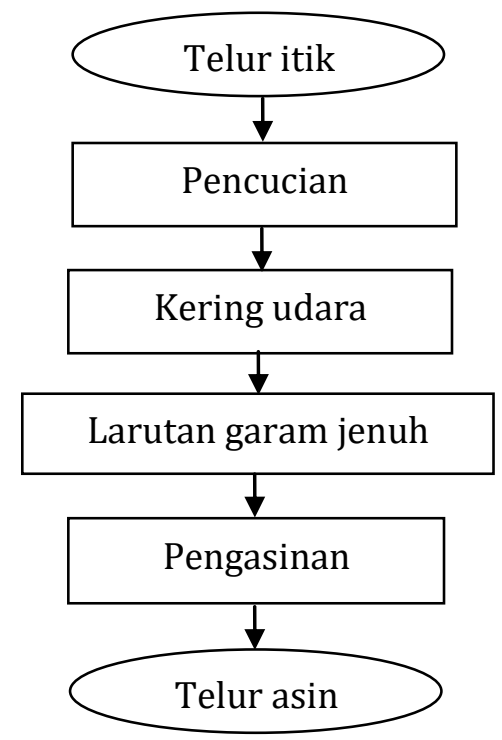

Gambar 1. Proses pembuatan telur asin

Analisisis Kadar Lemak. Rata-rata persentase nilai kadar lemak kuning telur itik yang direndam larutan garam jenuh dengan perlakuan $0,3,6,9,12,15,18$, dan 21 hari adalah berturut-turut 21,14\%, $31,59 \%, 36,73 \%, 37,74 \%, 27,49 \%, 26,22$ $\%$, 25,57 \%, dan 21,23 \%. Hasil persentase nilai kadar lemak putih telur itik yang direndam larutan garam jenuh dengan perlakuan 0 hari $(0,19 \%), 3$ hari $(0,69 \%)$, 6 hari $(1,3 \%), 9$ hari $(0,49 \%), 12$ hari $(0,24 \%), 15$ hari $(0,06 \%), 18$ hari $(0,04$ $\%)$, dan 21 hari $(0,23 \%)$. Hasil analisis ragam menunjukkan bahwa lama pengasinan kuning telur $(\mathrm{P}=128,94)$ dan putih telur $(\mathrm{P}=0,178)$ adalah tidak berpengaruh nyata $(P>0,05)$. Gambar 2 menunjukkan perbandingan kadar lemak kuning telur dan putih telur pada pembuatan telur asin dengan cara basah.

Tabel 2 menunjukkan bahwa masing-masing waktu (hari) pengasinan tidak berpengaruh nyata $(\mathrm{P}<0,05)$. Kandungan lemak putih telur tertinggi terdapat pada lama pengasinan di hari ke$6(1,30 \%)$, sedangkan kandungan lemak putih telur terendah terdapat pada hari ke-18 (0,04\%). 
Tabel 2. Rata-rata (\%)kadar lemak, kadar $\mathrm{pH}$, kadar $\mathrm{NaCl}$, dan kadar air pada telur asin

\begin{tabular}{ccccccccc}
\hline Perlakuan & $\begin{array}{c}\text { Kadar } \\
\text { lemak KT }\end{array}$ & $\begin{array}{c}\text { Kadar } \\
\text { lemak } \\
\text { PT }\end{array}$ & $\begin{array}{c}\text { Kadar } \\
\text { pH KT }\end{array}$ & $\begin{array}{c}\text { Kadar } \\
\text { pH PT }\end{array}$ & $\begin{array}{c}\text { Kadar } \\
\text { NaCl KT }\end{array}$ & $\begin{array}{c}\text { Kadar } \\
\text { NaCl PT }\end{array}$ & $\begin{array}{c}\text { Kadar } \\
\text { air KT }\end{array}$ & $\begin{array}{c}\text { Kadar } \\
\text { air PT }\end{array}$ \\
\hline 0 hari & 21,14 & 0,19 & 6,49 & 9,40 & 0,45 & 0,10 & 52,97 & 14,08 \\
3 hari & 31,59 & 0,69 & 6,70 & 9,25 & 1,30 & 1,95 & 52,15 & 13,96 \\
6 hari & 36,73 & 1,30 & 6,75 & 9,28 & 2,10 & 1,40 & 65,51 & 15,31 \\
9 hari & 37,74 & 0,49 & 6,51 & 9,12 & 1,95 & 1,40 & 65,96 & 15,44 \\
12 hari & 27,49 & 0,24 & 6,79 & 8,06 & 2,15 & 1,35 & 64,00 & 14,27 \\
15 hari & 26,22 & 0,06 & 6,90 & 8,60 & 2,00 & 1,55 & 65,34 & 14,64 \\
18 hari & 25,57 & 0,04 & 6,64 & 8,62 & 1,95 & 1,95 & 57,98 & 14,77 \\
21 hari & 21,23 & 0,23 & 6,42 & 8,20 & 2,15 & 2,05 & 59,96 & 15,60 \\
Mean & 128,94 & 0,18 & 0,16 & 0,34 & 0,71 & 0,77 & 63,93 & 0,81 \\
\hline Square & & & & & & & & \\
\hline
\end{tabular}

Ket. $\quad$ KT $=$ Kuning Telur

PT $=$ Putih Telur

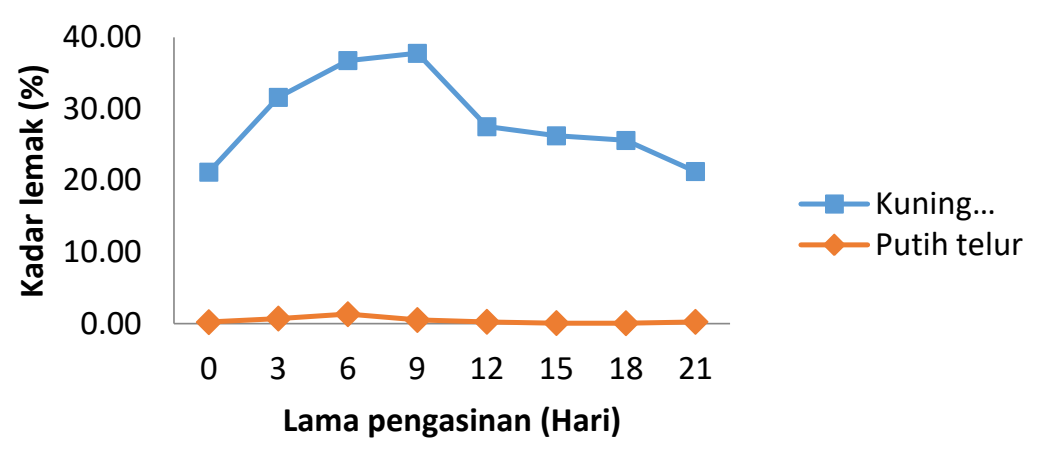

Gambar 2. Kadar lemak kuning dan putih telur asin

Gambar 2 menunjukkan kadar lemak kuning telur terendah terdapat pada hari ke-0 (21,14\%), sedangkan kadar lemak kuning telur tertinggi terdapat pada lama pengasinan di hari ke-9 (37,74\%)karena LowDensityLipoprotein (LDL) yang terdapat pada lemak bereaksi dengan garam sehingga struktur LDL menjadi rusak kemudian lemak yang yang dikandungnya menjadi bebas dan muncul di permukaan. Hal ini sesuai dengan pernyataan(Ganesan et al. 2014;0ktaviani et al. 2012)bahwa proses pengasinan dapat menyebabkan kenaikan nilai kadar lemak dengan mekanisme bahwa selama pengasinan LDL yang terdapat pada lemak bereaksi dengan garam sehingga struktur LDL menjadi rusak kemudian lemak yang yang dikandungnya menjadi bebas dan muncul di permukaan.

Analisis Nilai pH Telur. Rata-rata persentase nilai $\mathrm{pH}$ kuning telur itik yang direndam larutan garam jenuhdengan perlakuan $0,3,6,9,12,15,18$, dan 21 hari adalah berturut-turut $6,49 \%, 6,70 \%$, 6,75\%, 6,51\%, 6,79\%, 6,90 \%, 6,64\%, dan $6,42 \%$. Hasil persentase nilai pH putih telur itik yang direndam larutan garam jenuh dengan perlakuan $0,3,6,9,12,15$, 18, dan 21 hari adalah berturut-turut $9,40 \%, 9,25 \%, 9,28 \%, 9,12 \%, 8,06 \%, 8,60$ $\%, 8,62 \%$, dan 8,20 \%. Hasil analisis ragam menunjukkan bahwa lama pengasinan kuning telur $(\mathrm{P}=0,16)$ dan putih telur $(\mathrm{P}=0,340)$ adalah tidak berpengaruh nyata $(\mathrm{P}>0,05)$. Gambar 3 
menunjukkan perbandingan Nilai $\mathrm{pH}$ pembuatan telur asin dengan cara basah. kuning telur dan putih telur pada

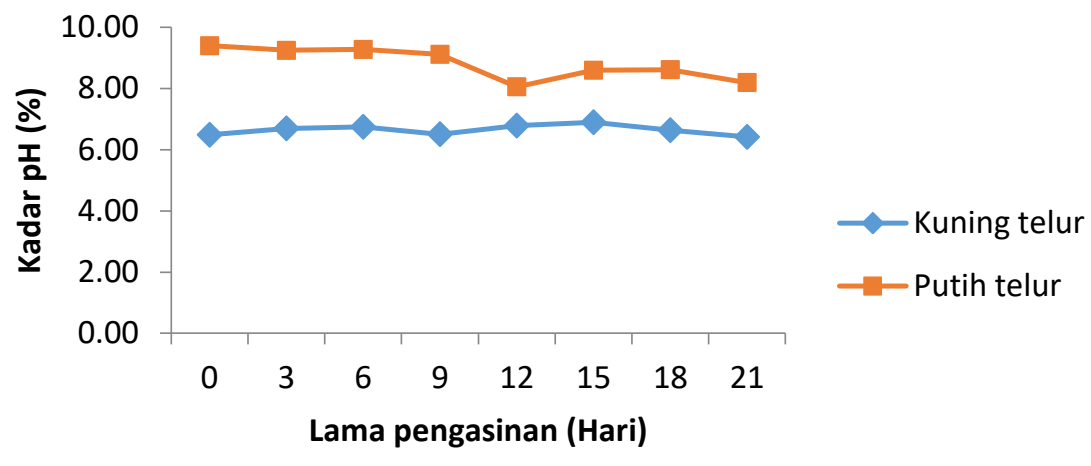

Gambar 3. Kadar pH kuning dan putih telur asin

Tabel 2 menunjukkan bahwa masing-masing waktu (hari) pengasinan tidak berpengaruh nyata $(\mathrm{P}<0,05)$. Kadar $\mathrm{pH}$ kuning telur tertinggi terdapat pada lama pengasinan di hari ke-15 (6,90\%), sedangkan kadar pH kuning telur terendah terdapat pada hari ke$21(6,42 \%)$. Kadar $\mathrm{pH}$ putih telur tertinggi terdapat pada lama pengasinan di hari ke$0(9,4 \%)$, sedangkan kadarpH putih telur terendah terdapat pada hari ke-12 $(8,06 \%)$.Semakin lama waktu pengasinan maka kadar $\mathrm{pH}$ putih telur dan kuning telur semakin menurun karena belum banyak penguapan $\mathrm{CO}_{2}$ dan $\mathrm{H}_{2} \mathrm{O}$ yang terdapat pada telur. Hal ini didukung (Sihombing et al. 2014) yang melaporkan bahwa kadar $\mathrm{pH}$ telur yang diasinkan akan mengalami peningkatan jika terjadi banyak penguapan $\mathrm{CO}_{2}$ sehingga menyebabkan alkalis yang berakibat $\mathrm{pH}$ telur meningkat.

Analisis Kadar NaCl Telur. Ratarata persentase kadar $\mathrm{NaCl}$ kuning telur itik yang direndam larutan garam jenuh dengan perlakuan $0,3,6,9,12,15,18$, dan 21 hari adalah berturut-turut 0,45 \%, 1,30 $\%, 2,10 \%, 1,95 \%, 2,15 \%, 2 \%, 1,95 \%$, dan 2,15\%. Hasil persentase kadar $\mathrm{NaCl}$ putih telur itik yang direndam larutan garam jenuh dengan perlakuan $0,3,6,9,12,15$, 18, dan 21 hari adalah berturut-turut 0,10 $\%, 1,95 \%, 1,4 \%, 1,4 \%, 1,35 \%, 1,55 \%$, $1,95 \%$, dan 2,05 \%. Hasil analisis ragam menunjukkan bahwa lama pengasinan kuning telur $(\mathrm{P}=0,708)$ dan putih telur $(\mathrm{P}=0,773)$ adalah tidak berpengaruh nyata $(\mathrm{P}>0,05)$. Gambar 4 menunjukkan perbandingan kadar $\mathrm{NaCl}$ kuning telur dan putih telur pada pembuatan telur asin dengan cara basah.

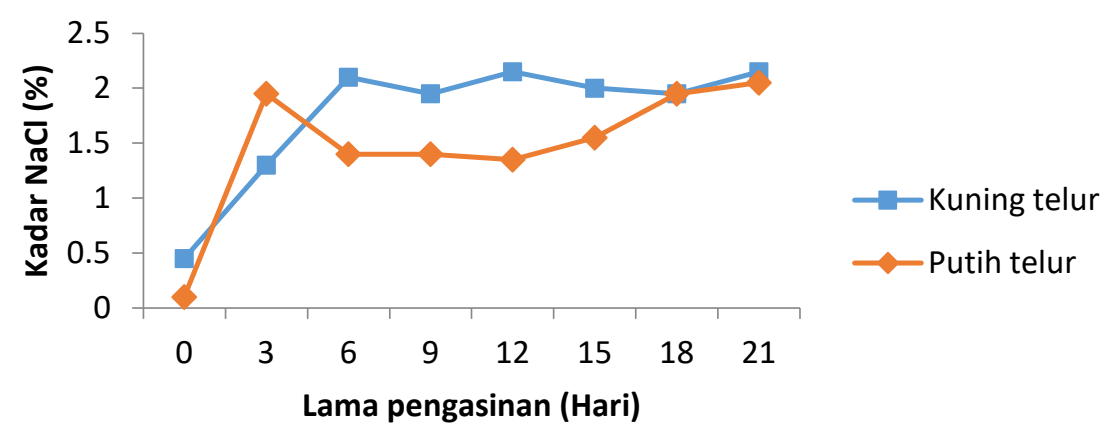

Gambar 4. Kadar $\mathrm{NaCl}$ kuning dan putih telur asin 
Tabel 2 menunjukkan bahwa masingmasing waktu (hari) pengasinan tidak berpengaruh nyata $(\mathrm{P}<0,05)$. Kadar $\mathrm{NaCl}$ kuning telur tertinggi terdapat pada lama pengasinan di hari ke-12 (2,15\%), sedangkan kadar $\mathrm{NaCl}$ kuning telur terendah terdapat pada hari ke-0 $(0,45 \%)$. Kadar $\mathrm{NaCl}$ putih telur tertinggi terdapat pada lama pengasinan di hari ke-21 $(2,05 \%)$, sedangkan kadar $\mathrm{NaCl}$ putih telur terendah terdapat pada hari ke-0 $(0,10 \%)$. Gambar 4 menunjukkan semakin lama waktu pengasinan maka semakin tinggi kadar $\mathrm{NaCl}$ kuning telur dan putih telur karena terjadinya difusi secara osmosis sehingga terjadi migrasi air garam ke dalam telur. Hal ini sesuai dengan penelitian (Kaewmanee et al. 2009) yang menyatakan bahwa semakin lama waktu pengasinan maka kadar $\mathrm{NaCl}$ kuning telur maupun putih telur semakin meningkat yang disebabkan karena proses osmosis.

Analisis Kadar Air Telur. Ratarata persentase kadar air kuning telur itik yang direndam larutan garam jenuh dengan perlakuan $0,3,6,9,12,15,18$, dan 21 hari adalah berturut-turut 52,97\%, $52,19 \%, 65,51 \%, 65,96 \%, 64 \%, 65,34 \%$, $57,98 \%$, dan 59,96\%. Hasil persentase kadar air putih telur itik yang direndam larutan garam jenuh dengan perlakuan 0 , $3,6,9,12,15,18$, dan 21 hari adalah berturut-turut 14,07 \%, 13,96\%, 15,31\%, $15,44 \%, 14,27 \%, 14,64 \%, 14,77 \%$, dan $15,60 \%$ Hasil analisis ragam menunjukkan bahwa lama pengasinan kuning telur $(\mathrm{P}=63,930)$ dan putih telur $(\mathrm{P}=0,809)$ adalah tidak berpengaruh nyata $(P>0,05)$. Gambar 5 menunjukkan perbandingan kadar air kuning telur dan putih telur pada pembuatan telur asin dengan cara basah.

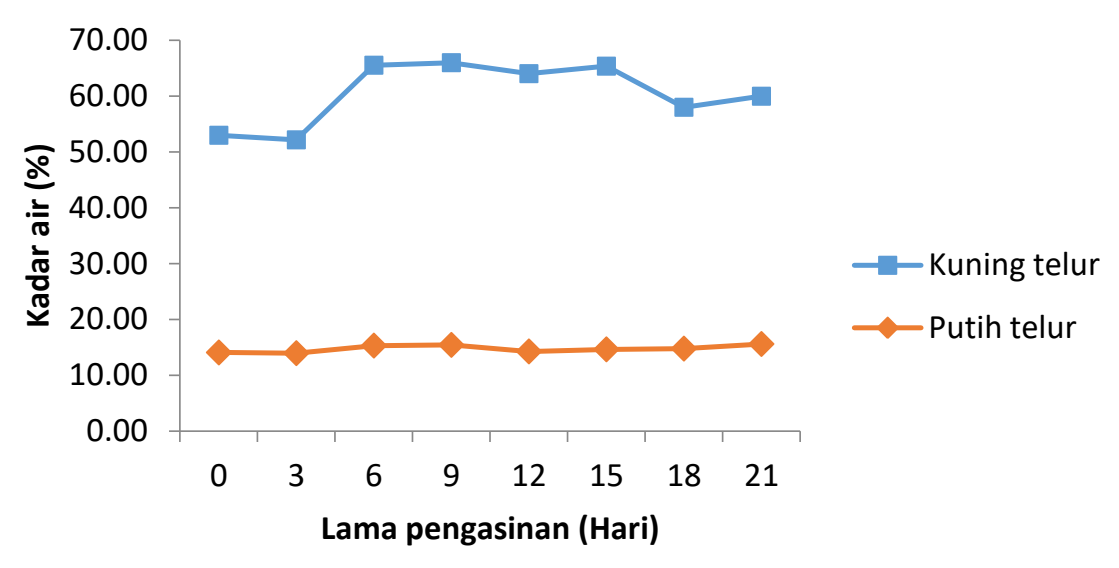

Gambar 5. Kadar air kuning dan putih telur asin

Tabel 2 menunjukkan bahwa masingmasing waktu (hari) pengasinan tidak berpengaruh nyata $(\mathrm{P}<0,05)$. Kadar air kuning telur tertinggi terdapat pada lama pengasinan di hari ke-9 $(65,96 \%)$, sedangkankadar air kuning telur terendah terdapat pada hari ke-3 (52,15\%). Menurut(Wang et al. 2013; Chi and Tseng, 1998) bahwa seslama pengasinan terjadi perpindahan air dari kuning telur menuju putih telur. Kadar air putih telur tertinggi terdapat pada lama pengasinan di hari ke-
21 (15,60\%), sedangkan kadar air putih telur terendah terdapat pada hari ke-0 (14,07 \%). Gambar 5 menunjukkan kadar air putih telur lebih rendah dibandingkan dengan kuning telur karena migrasi air dari putih telur lebih besar ke larutan garam jenuh. Hal ini sesuai dengan (Kaewmanee et al. 2009) yang menyatakan bahwa migrasi putih telur terutama terjadi pada permukaan telur yang diasinkandan ditandai dengan proses osmosis. 


\section{KESIMPULAN}

Kesimpulanpenelitian ini adalah hasil analisis ragam Anova yang didapatkan bahwa pengaruh lama pengasinan $0,3,6,9,12,15,18$, dan 21 hari terhadap kadar lemak, $\mathrm{pH}, \mathrm{NaCl}$, dan kadar air telur itik adalah tidak berpengaruh nyata.

\section{DAFTAR PUSTAKA}

Chi SP, \&Tseng KH. 1998. Physicochemical Properties of Salted Pickled Yolks from Duck and Chicken Eggs. J Food Sci, 63(1), 27-30. https://doi.org/10.1111/j.13652621.1998.tb15668.x

Djaelani MA. 2016. Ukuran rongga udara, $\mathrm{pH}$ telur dan diameter putih telur, ayam ras (Gallus L) setelah pencelupan dalam larutan rumput laut dan disimpanan beberapa waktu. Buletin Anatomi Dan Fisiologi, 1, 1923.

Ganesan P, Kaewmanee T, Benjakul S, Baharin BS. 2014. Comparative Study on the Nutritional Value of Pidan and Salted Duck Egg Comparative Study on the Nutritional Value of Pidan and. Korean J. Food Sci. An., 34, 1-6. https://doi.org/10.5851/kosfa.2014. 34.1 .1

Kaewmanee T, Benjakul S, Visessanguan W. 2009. Effect of salting processes on chemical composition, textural properties and microstructure of duck egg. JSci Food Agric, 89(4), 625633.

https://doi.org/10.1002/jsfa.3492

Lesmayati S\& Rohaeni ES. 2014. Pengaruh Lama Pemeraman Telur Asin Terhadap Tingkat Kesukaan Konsumen. In Prosiding Seminar Nasional "Inovasi Teknologi Pertanian Spesifik Lokasi" (pp. 595-601).

PurbaM \&SinuratAP. 2015. Produksi telur, konsumsi dan efisiensi pakan itik
PMp yang diberi ransum dengan kandungan energi dan lisin yang berbeda selama tiga bulan produksi. In Prosiding Seminar Nasional Teknologi Peternakan dan Veteriner (pp. 472-478).

Novia D, Melia S, Juliyasari I. 2014. Utilization of Ash in the salting process on Mineral content raw salted eggs. Asian J. of Poult Sci, 8, 18.

Octarisa R, Santoso RSS, Sukardi. 2013. Pengaruh Perbandingan Tepung Tapioka Dengan Telur Asin Dan Lama Pengukusan Pada Pembuatan Kerupuk Telur Terhadap Kadar Garam Dan Kesukaan Rasa. Jurnal Ilmiah Peternakan, 1(April), 157-162.

Oktaviani H, Kariada N, Utami NR. 2012. Pengaruh pengasinan terhadap kandungan zat gizi telur bebek yang diberi limbah udang. Unnes Journal of Life Science, 1, 106-112.

HarmayandaPOA, Rosyidi D, Sjofjan O. 2016. Evaluasi Kualitas Telur Dari Hasil Pemberian Beberapa Jenis Pakan Komersial Ayam Petelur. J-Pal, 7(1), 25-32.

Sihombing R, Kurtini T, Nova K. 2014. Pengaruh Lama Penyimpanan Terhadap Kualitas Internal Telur Ayam Ras Pada Fase Kedua, 81-86.

SNI, 1992. Standar Nasional Indonesia (SNI 01-2891): Cara Uji Makanan dan Minuman.

Wang X, GaoZ, Xiao H, Wang Y, Bai J. 2013. Enhanced mass transfer of osmotic dehydration and changes in microstructure of pickled salted egg under pulsed pressure. J. Food Eng.117(1), 141-150. https://doi.org/10.1016/j.jfoodeng.2 013.02.013

Wibawanti JM, Meihu M, Hintono A, Pramono YB. 2013. The characteristic of salted egg in the presence of liquid smoke. JAFT, 2, 68-70. https://doi.org/10.3969/J.

Wibowo RH. 2011. Analisa Usaha UKM 
Ternak Itik Petelur (Studi kasus di daerah Cirebon, Jawa Barat).

Zhao Y, Chen Z, Li J, Xu M, Shao Y, Tu Y. 2016. Changes of microstructure characteristics and intermolecular interactions of preserved egg white gel during pickling. Food Chem, 203, 323-330.

https://doi.org/10.1016/j.foodchem. 2016.02.044 